\title{
Effects of compaction on the erodibility of a residual soil of gneiss
}

\author{
Marcelo Heidemann ${ }^{1, *}$, Helena P. Nierwinski ${ }^{1}$, Bruna Sell ${ }^{1}$, Paulo Vinícius da Silva ${ }^{1}$ \\ ${ }^{1}$ Federal University of Santa Catarina, Joinville School of Technology, Dona Francisca St. 8300, 89219-600, Joinville, Brazil.
}

\begin{abstract}
This work aims to verify the effects of the natural structure of a residual soil on its erodibility and the potential, employing compaction, to restore the erosion resistance. It is a residual soil of gneiss that occurs in the state of Santa Catarina, Southern Brazil. Infrastructure earthworks expose this material to the action of water, which can develop severe erosive features. The erodibility evaluation was made using the MCT methodology based on infiltrability and modified loss of mass by immersion tests. These tests were conducted in undisturbed specimens at natural moisture content and in compacted specimens at optimum moisture content. Such tests were also carried out in specimens air-dried for 24,48 , and 96 hours. This soil is inherently erosive, but the natural macrostructure makes it even more susceptible to erosion. Even compaction under modified energy is not able to recover the erodibility resistance. Drying slightly reduces the soil's erosive potential when compacted, regardless of the compaction energy, but clearly increases the erosive potential of undisturbed soil.
\end{abstract}

\section{Introduction}

Erosion consists of processes by which materials from the earth's crust are removed and transported from one point to another to be deposited there. When erosion is caused by water, it is called hydric erosion (Bastos 1999 [1]). This process can be greatly accelerated through anthropic action. This is basically due to changes in topography, which promotes an increase in energy and the concentration of water flow and exposes soils to water action. In urban areas, water erosion causes problems to the infrastructure, such as the silting up of water bodies, reservoirs, and storm sewage networks, geometry changes of embankments inducing slope failures, the formation of gullies, and the degradation of bridge pillars and piers (Briaud \& Ho 2010 [2], Verstraeten \& Poesen 2000 [3], Vilar 1987 [4]).

Measuring soil erosion has been one of the main targets of scientific research and government programs since the beginning of the 20th century (Garcia-Ruiz et al. 2015 [5]), and given its environmental, economic, and social impacts, remains a relevant issue. Soil erodibility, according to Wang et al. (2013) [6], consists of the susceptibility of the soil to be eroded. Nogami \& Villibor (1995) [7] describe specific erodibility as the soil's intrinsic resistance to detaching particles under the dynamic action of surface flow and raindrops.

Among the properties of the soil that impact erodibility, shear strength, texture, permeability, mineralogy, and structure can be mentioned (Bastos 1999 [1], Wischmeier \& Smith 1978 [8], Watson \& Laflen 1986 [9], Kimiaghalam et al. 2016 [10], Duiker et al. 2001 [11], Lal 1990 [12]). The correlation between susceptibility to erosion and such properties is well explored when the MCT (Miniature Compacted Tropical) methodology (Nogami \& Villibor 1979 [13]) is used. Although its application is practically restricted to Brazil, several studies have shown interesting results when using this proposition, as shown by Bastos (1999) [1], Higashi (2006) [14], Molinero Junior (2010) [15] and Couto (2015) [16].

The MCT erodibility criterion was developed regarding to the behavior of tropical saprolitic and lateritic soils. The soil structure has strong control over such materials' geomechanical behavior, including erodibility, because it can provide an additional portion of shear resistance due to cohesion. According to Bastos (1999) [1], the silt fraction of kaolinitic-micaceous saprolitic soils, in contrast to temperate climate quartz silts, imposes high erodibility on tropical soils.

Compaction can also affect soil erodibility. According to Silva (2009) [17], the enveloping technique decreases the erodibility by around $70 \%$ compared to the unprotected soil. Hanson et al. (2010) [18] show that in the dry branch of the curves, the compaction moisture has a remarkable influence on erodibility, with the minimum erodibility being obtained in moisture levels close to the optimum moisture.

In the study area of this work, saprolitic gneiss soils are often excavated in earthworks and extracted for the construction of compacted landfills. In such cases, they are exposed to the action of rain, becoming more susceptible to erosion. Thus, this work presents a study about the effects of the structure of a residual soil of gneiss on its erodibility, and the potential, employing compaction, to restore the resistance against erosion.

\footnotetext{
* Corresponding author: marcelo.heidemann@ufsc.br
} 


\section{Materials and Methods}

\subsection{Study Area}

The municipality of Joinville is located in Southern Brazil. Its urban area extends predominantly over flat areas, which correspond to recent sedimentary deposits. Figure 1 shows the geological features of the municipality.

The urban occupation occurs on the sedimentary deposits and in some hilly areas that correspond to a metamorphic basement formed by gneisses and migmatites, which are characterized by thick weathering profiles (thicknesses greater than $50 \mathrm{~m}$ in certain cases). Due to urbanization, these hill lands are cut, and the soils are extracted to be used in landfills. Thus, the association of the exposure of these soils and the quite high rainfall levels (> $2000 \mathrm{~mm} /$ year) creates an environment in which water erosion is enhanced.

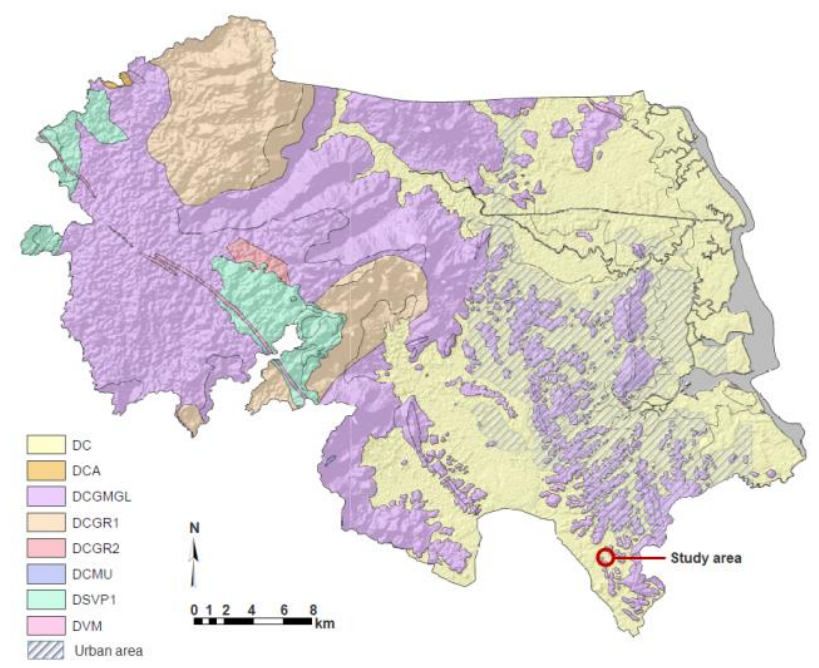

Fig. 1. Geological framework of Joinville; DC/DCA: unconsolidated Cenozoic sedimentary plains; DCGMGL: migmatite/gneiss/granulite; DCGR1/DCGR2: granitoid; DCMU: mafic/ultramafic bodies; DSVP1: Vulcan-sedimentary sequences; DVM: Mesozoic fissuring volcanism (data from CPRM, 2010 [19]).

\subsection{Experimental campaign}

The specimens were sampled in an area where the soil is exposed (Figure 2). Coordinates of the sampling area are 715094.56 E; 7078267.86 S, and $23 \mathrm{~m}$ above sea level.

The soil was sampled in an undisturbed and disturbed state. The undisturbed soil was sampled according to the procedures presented by ABNT NBR 9604 (2016) [20], in the saprolitic layer of the profile.

The physical characterization included tests of specific gravity (ASTM D854, 2014 [21]), consistency limits (ABNT NBR 6459, 2016 [22] and ABNT NBR 7180, 2016 [23]) and grain size distribution (ABNT NBR 7181, 2016 [24]). Sodium hexametaphosphate was used as a dispersive agent in the sedimentation analysis. Tests with suppression of dispersive agent were also carried out in order to evaluate the effects of structuring on the texture of the material.

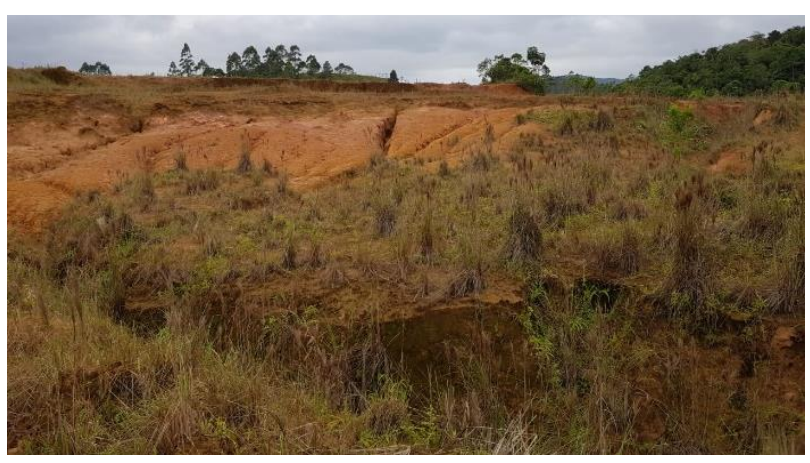

Fig. 2. Erosive features in the study area.

The compaction curves of the studied soil were determined for normal $\left(600 \mathrm{~kJ} / \mathrm{m}^{3}\right)$, intermediate $(1300$ $\left.\mathrm{kJ} / \mathrm{m}^{3}\right)$ and modified $\left(2750 \mathrm{~kJ} / \mathrm{m}^{3}\right)$ compaction energies, through Proctor compaction tests, according to ABNT NBR 7182 (2016) [25].

The erosive potential characterization was based on two tests: infiltrability and modified loss of mass by immersion. These tests are part of the MCT methodology's experimental procedures, proposed by Nogami \& Villibor (1979) [13]. These tests were carried out with undisturbed and compacted specimens.

The undisturbed specimens were extracted from blocks obtained in the field using cylindrical rings with the specific dimensions for the execution of infiltration tests (50 $\mathrm{mm}$ height and $48 \mathrm{~mm}$ diameter) and loss of mass by modified immersion $(25 \mathrm{~mm}$ height and $48 \mathrm{~mm}$ diameter). The compacted specimens were extracted from compacted soil specimens in the $1000 \mathrm{~cm}^{3}$ cylinders used for Proctor compaction tests. Compaction was carried out with the soil at optimum moisture content for each of the energies abovementioned. The tests were carried out on specimens under natural or molding moisture and airdried for 24,48 , and $96 \mathrm{~h}$. A total of 32 specimens were prepared: 16 for infiltration tests and 16 for modified loss of mass by immersion tests. The conditions and identification of the specimens are described in Table 1.

Table 1. Identification of tested specimens.

\begin{tabular}{c|cccc}
\hline & $\begin{array}{c}\text { Undistur- } \\
\text { bed }\end{array}$ & $\begin{array}{c}600 \\
\mathrm{~kJ} / \mathrm{m}^{3}\end{array}$ & $\begin{array}{c}1300 \\
\mathrm{~kJ} / \mathrm{m}^{3}\end{array}$ & $\begin{array}{c}2750 \\
\mathrm{~kJ} / \mathrm{m}^{3}\end{array}$ \\
\hline $\begin{array}{c}\text { Natural / } \\
\text { optimum } \\
\text { moisture (UM) }\end{array}$ & IND-UM & EN-UM & EI-UM & EM-UM \\
Air dried 24 h & IND-24 & EN-24 & EI-24 & EM-24 \\
Air dried 48 h & IND-48 & EN-48 & EI-48 & EM-48 \\
Air dried 96 h & IND-96 & EN-96 & EI-96 & EM-96 \\
\hline
\end{tabular}

In the infiltrability test, one measures the water rate that infiltrates by capillarity and its variation over time. This test is performed by subjecting a soil specimen to the distilled water's infiltration in a circular tube $(5 \mathrm{~mm}$ diameter). The displacement of the meniscus (water infiltration) is then measured over time, and the data is plotted in a graph that shows the infiltrated volume versus 
the root of time. The initial slope of this graph corresponds to the coefficient of sorption $(s)$.

The modified loss of mass by immersion test is based on the test proposed by DNER ME 256 (1994) [26]. In this test the specimen, confined laterally by a ring and by a porous stone in one of its faces, is immersed for a period of 20 hours. After this period, the percentage of the solid particles disaggregated in relation to the initial mass of solid particles is determined (parameter pi). The test modification refers to the use of specimens whose face coincides with the limit of the ring (different from the original test in which part of the soil is partially extruded from the ring). The use of the modified procedure is reported by Bastos (1999) [1], Higashi (2006) [14], and Heidemann et al. (2018) [27].

The erosive potential is given by the $\mathrm{pi} / \mathrm{s}$ ratio, here named erodibility (E). According to Nogami \& Villibor (1979) [13], soils with $\mathrm{E}>52$ should be considered as having high erosive potential, while Pejon (1992) [28] proposed a limit criterion given by $\mathrm{E}>40$.

\section{Results}

Table 2 shows the physical indexes of the soil in its natural state. The grain size curves of the studied soil are shown in Figure 3.

Table 2. In situ properties of the studied soil.

\begin{tabular}{cc}
\hline $\mathrm{G}$ & 2.712 \\
Wnat $(\%)$ & 25.0 \\
$\gamma_{\mathrm{d}, \text { nat }}\left(\mathrm{kN} / \mathrm{m}^{3}\right)$ & 14.7 \\
$\mathrm{~S}_{\mathrm{r}}(\%)$ & 78.7 \\
$\mathrm{e}$ & 0.85 \\
$\mathrm{wL}$ & 45 \\
$\mathrm{PI}$ & 16 \\
\hline
\end{tabular}

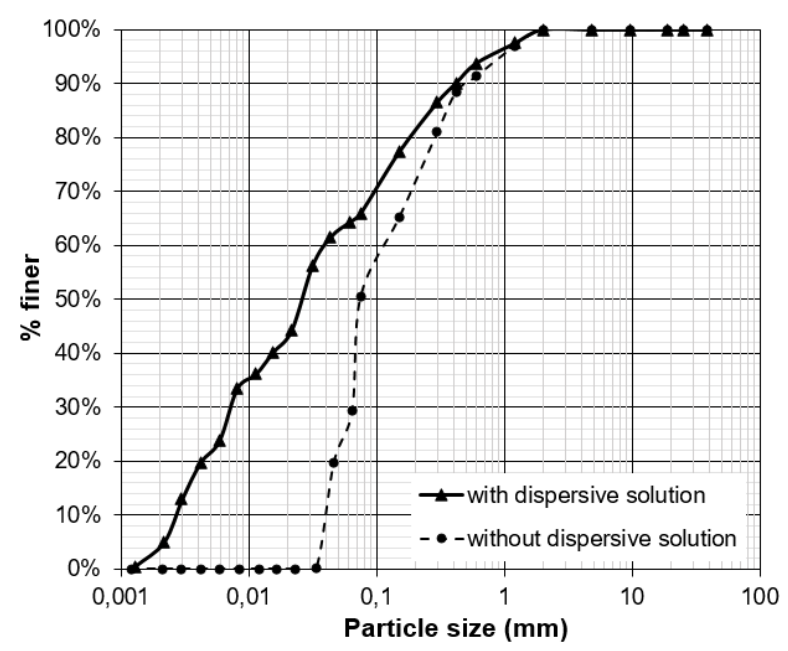

Fig. 3. Grain size curves.

The studied soil is a silt, with high plasticity, being classified as ML according to the USCS system (ASTM D4287, 2017 [29]). According to Nogami \& Villibor (1995) [7], soils with such characteristics are inherently susceptible to erosion
The difference between the grain size curves demonstrates the dispersive solution's effect on the macro-structural features, such as concretions and pseudomorphic minerals. It also shows that in situ, this soil contains lumps with sand size formed by particles with predominantly silt size. As there is no percolation of fluid in the field that has an effect similar to that of the deflocculating solution, it is debatable the establishment of parameters of erodibility derived from textural features (obtained traditionally) for residual soils, especially those composed of fine particles.

The compaction curves are shown in Figure 4, and the physical indices of the compacted soil at the optimum moisture content for normal, intermediate, and modified energies are shown in Table 3. Compared to the soil in a natural state, compaction under modified energy promotes an increase in apparent dry weight $\left(\gamma_{\mathrm{d}}\right)$ about $20 \%$, and a reduction of $40 \%$ in the void ratio. The physical indices in Table 3 were used as a reference in the preparation of the compacted specimens used in the tests of infiltrability and loss of mass by immersion.

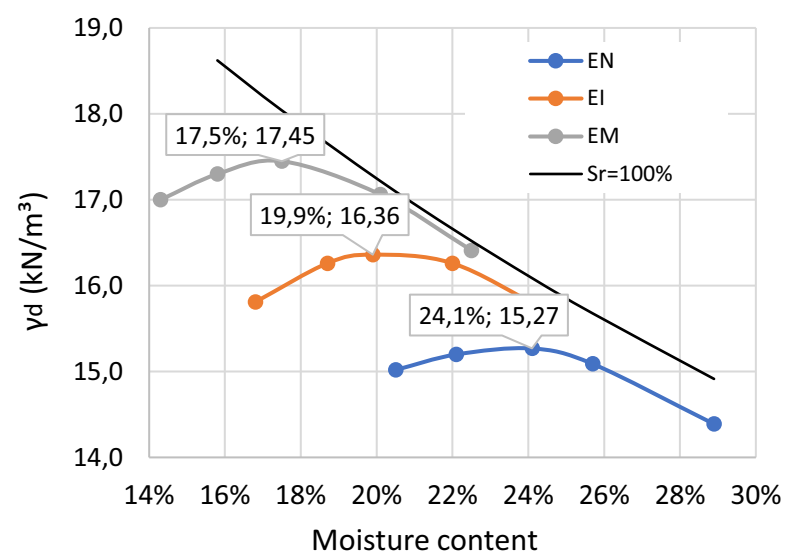

Fig. 4. Compaction curves for different compaction energies.

Table 3. Properties of the compacted soil under different compaction energies.

\begin{tabular}{cccc}
\hline & EN & EI & EM \\
\hline $\mathrm{W}_{\text {opt }}(\%)$ & 24.1 & 19.9 & 17.5 \\
$\gamma_{\mathrm{d}, \max }\left(\mathrm{kN} / \mathrm{m}^{3}\right)$ & 15.3 & 16.4 & 17.4 \\
$\mathrm{e}(\%)$ & 0.74 & 0.63 & 0.53 \\
$\mathrm{~S}_{\mathrm{r}}$ & 86.0 & 88.1 & 90.4 \\
\hline
\end{tabular}

The results of the infiltration tests are shown in Figure 5. The specimens are named as described in Table 1. This figure shows a general trend, both in the increase in the infiltration rate (slope of the curves) and in the total infiltrated volume as the drying time increases. In the field, infiltration reduces the amount of water on the surface and, consequently, the intensity of the surface flow, responsible for triggering erosion. 

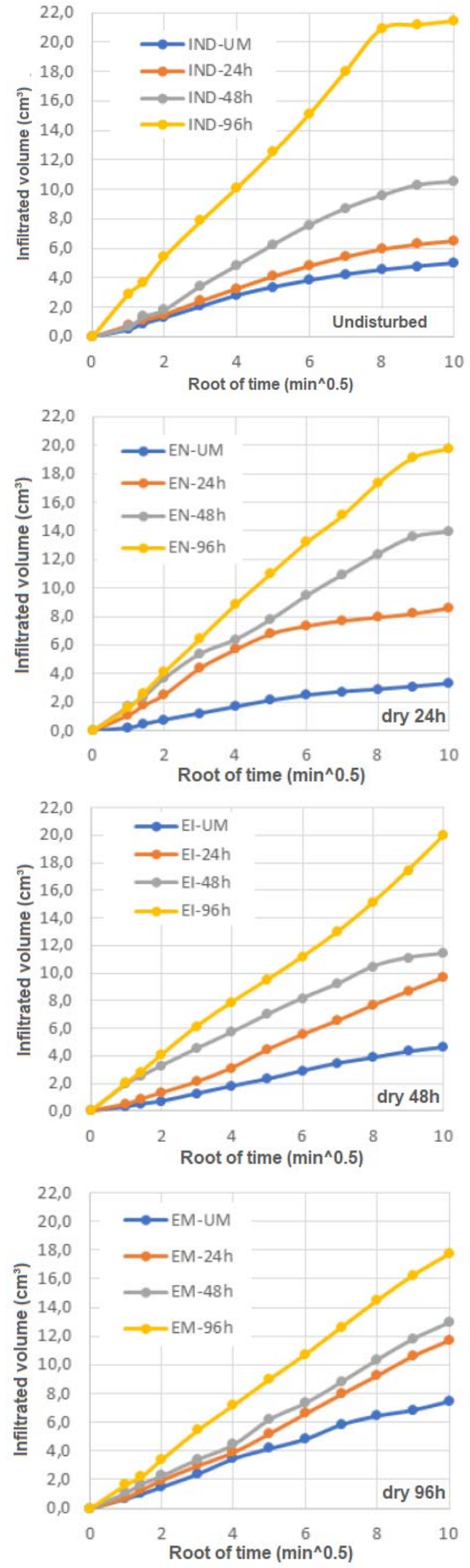

Fig. 5. Results of infiltrability tests.

It is also a trend that the increase in the compaction energy and higher initial moisture reduce the sorption coefficient, as shown in Figure 6, which summarizes the results in terms of variation of this coefficient. The increase of compaction energy reduces the sorption coefficient just on dry specimens air-dried during 48 and $96 \mathrm{~h}$. For the soil tested under optimum moisture, the increase in compaction energy also increases the sorption coefficient because the specimens are less humid at the beginning of the test and, therefore, more susceptible to water infiltration.

The results of the modified immersion mass loss tests, summarized in Figure 7, show clear behavioral differences between the undisturbed and compacted soil. The soil structure imposes a much greater resistance to the loss of mass, and in natural moisture, the compacted soil loses about six times more mass than the undisturbed material.



Fig. 6. Measured values of sorption coefficient.

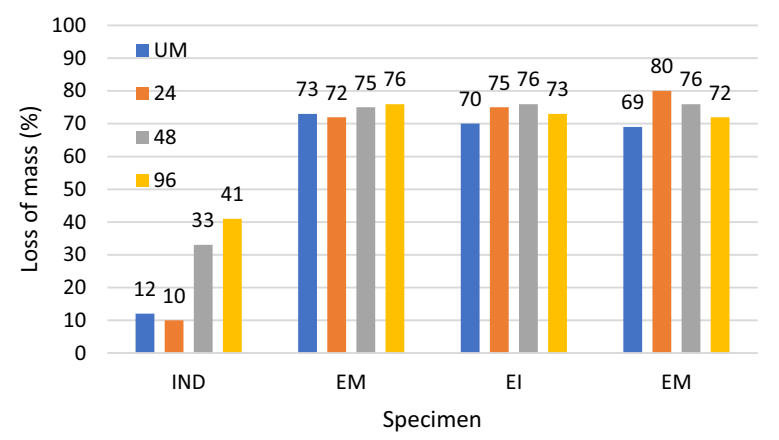

Fig. 7. Measured values of loss of mass by immersion.

Drying does not affect the loss of mass of the compacted soil. In this sense, the undisturbed soil is much more sensitive. Drying causes volumetric strains, which in the undisturbed soil could impose cracks, as observed in the specimens tested. In the compacted soil, structural features like cohesion are absent and, therefore, the volumetric variations, normally smaller due to compaction, have no greater effects.

Figure 8 shows the results in terms of the erodibility parameter of the MCT criterion $(\mathrm{E}=\mathrm{pi} / \mathrm{s})$. It is noticed that both erodibility criteria reported, that is, $\mathrm{E}=52$ (Nogami \& Villibor 1979) [13] and $E=40$ (Pejon 1992) [28] qualify this soil as erosive. The soil in the undisturbed state is less erosive than when compacted, mainly as a result of its lower loss of mass. The arrow in Figure 8 points towards the trend of increasing erodibility, in the undisturbed soil, due to drying.

Comparatively, the effects of the compaction energy variation and drying before the test on the compacted soil's erosive potential are much less, since all the points 
are grouped in the same region of the graph. Even so, in the case of compacted soil, it appears that drying reduces the erosive potential.

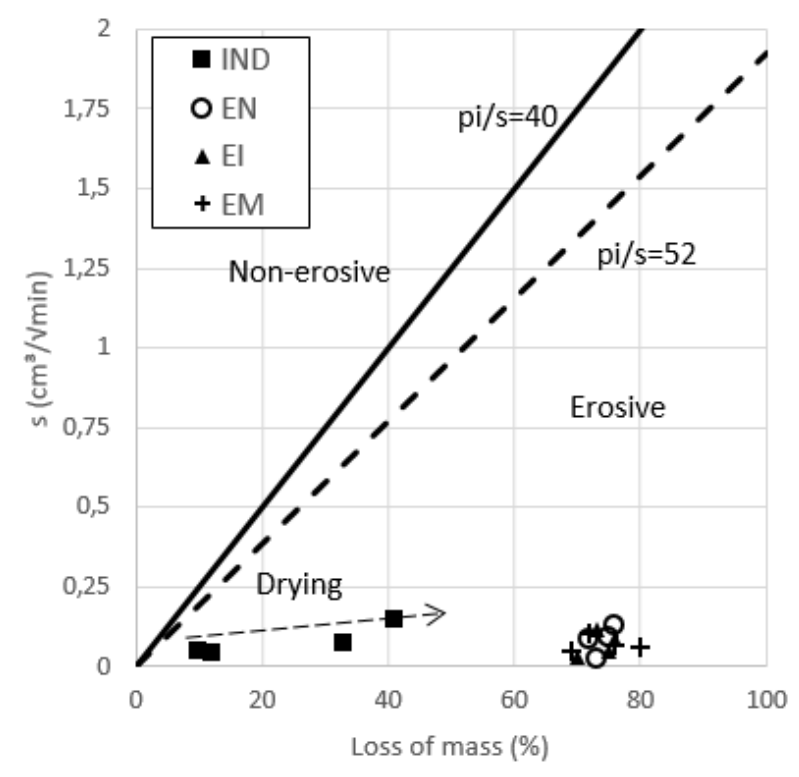

Fig.8. Erodibility of the studied soil.

\section{Conclusions}

The studied soil corresponds to a high plasticity silt. Conventional particle size tests point to a clay percentage below $10 \%$. Tests without the use of a dispersive solution show that, in a natural state, particles smaller than 0.03 $\mathrm{mm}$ are mostly grouped, forming lumps of silt and fine sand size. Hence, it is debatable to correlate erodibility potential from textural features (obtained through the traditional process) for fine residual soils.

The erodibility tests show that the soil's natural structure has a significant impact on its erosive potential. The undisturbed soil presents erodibility parameter "E" lower than those measured in compacted soil for all the moisture conditions considered. However, even at natural moisture content, this soil is classified as erosive by both used criteria $(E=40$ and $E=52)$.

Drying increases the erosive potential of the undisturbed soil. Despite promoting an increase in the sorption coefficient (which is important to the resistance to erosion), it also significantly increases the loss of mass.

Compaction is unable to give significant resistance to erosion for this soil, regardless of the compaction effort. Infiltrability and loss of mass by immersion are little affected by the variation in compaction energy.

Considering the results obtained, earthworks that involve exposure and movement of this soil must consider measures that aim to protect this material from rain and runoff. The adoption of higher compaction energies as a way to reduce erosion potential is not justified.

\section{References}

1. C.A.B. Bastos. (1999). Estudo Geotécnico sobre a Erodibilidade de Solos Residuais Não Saturados. Tese, PPGEC/UFRGS. Porto Alegre

2. J.L. Briaud, S.J. Oh. (2010). Bridge foundation scour. Geotech. Eng. J. 41. 1-16

3. G. Verstraeten, J. Poesen. (2000). Estimating trap efficiency of small reservoirs and ponds: methods and implications for the assessment of sediment yield. Progress in Physical Geography. 24.

4. O.M. Vilar. (1987). Formulação de um Modelo Matemático para Erosão dos Solos pela Chuva. Tese, EESC/USP. São Carlos.

5. J.M. García-Ruiz, et al. (2015). A meta-analysis of soil erosion rates across the world. Geomorphology, 239, 160-173.

6. B. Wang, F. Sheng, M.J.M, Römkens, F. Darboux. (2013). Soil erodibility for water erosion: A perspective and Chinese experiences. Geomorphology. 187. 1-10.

7. J.S. Nogami, D.F. Villibor. (1995). Pavimentação de baixo custo com solos lateríticos (Editora Villibor). São Paulo.

8. W.H. Wischmeier, D.D. Smith. (1978). Predicting rainfall erosion losses: a guide to conservation planning. Agricultural Handbook, 537. U.S. Dep. Agriculture.

9. D.A.Watson, J.M. Laflen. (1986). Soil strength, slope and rainfall intensity effects on the interrill erosion. Transactions of ASAE, 29:1.

10. N. Kimiaghalam, S.P. Clark, H. Ahmari. (2016). An experimental study on the effects of physical, mechanical and electrochemical properties of natural cohesive soils on critical shear stress and erosion rate. Int. J. Sediment Research. 31, 1-15

11. S.W. Duiker, D.C. Flanagan, R. Lal. (2001). Erodibility and infiltration characteristics of five major soils of southwest Spain. Catena, 45, 103-121.

12. R. Lal. (1990). Soil Erosion and Land Degradation: The Global Risks. Lal R. \& Stewart B.A. ed. Advances in Soil Science, 11. Springer, New York.

13. J.S. Nogami, D.F. Villibor. (1979). Soil characterization of mapping units for highway purposes in a tropical area. Bul. Int. Ass. Eng. Geology. 19:196

14. R.A.R. Higashi. (2006). Metodologia de uso e ocupação dos solos de cidades costeiras brasileiras através de SIG com base no comportamento geotécnico e ambiental. Tese, PPGEC/UFSC: Florianópolis.

15. J.A. Molinero Junior. (2010). Estudo geotécnico dos solos de erosões resultantes de intervenções em rodovias. Dissertação, PPGEC/UFU. Uberlândia.

16. B.O.C. Couto. (2015). Análise da erodibilidade em taludes com horizontes resistentes e suscetíveis aos processos erosivos. Dissertação, POSGEO/UFOP, Ouro Preto. 
17. D.J.B.V. Silva. (2009). Avaliação de métodos de baixo custo para proteção de taludes em estradas rurais não-pavimentadas. Dissertação, UNESP. Ilha Solteira.

18. G.J. Hanson, T.L. Wahl, D.M. Temple. (2010). Erodibility characteristics of embankment materials, Dam Safety 2010, Seattle.

19. CPRM. (2010) Mapa Geodiversidade do Estado de Santa Catarina, escala 1:500.000. rigeo.cprm.gov.br/jspui/handle/doc/14712

20. ABNT. (2016). Abertura de poços e trincheiras de inspeção em solo, com retirada de amostras deformadas e indeformadas: NBR 9604. Rio de Janeiro.

21. ASTM. (2014). Standard Test Methods for Specific Gravity of Soil Solids by Water Pycnometer D854-14. Int. West Conshohocken.

22. ABNT. (2016). Determinação do limite de liquidez: NBR 6459. Rio de Janeiro.

23. ABNT. (2016). Determinação do limite de plasticidade: NBR 7180. Rio de Janeiro.

24. ABNT. (2016). Análise granulométrica: NBR 7181. Rio de Janeiro.

25. ABNT. (2016). Ensaio de Compactação: NBR 7182. Rio de Janeiro.

26. DNER. (1994). Solos compactados com equipamento miniatura - determinação da perda de massa por imersão: DNER-ME 256/94.

27. Heidemann, M. et al. (2018). Efeitos da estrutura sobre o potencial erosivo de solos residuais de gnaisse do norte de Santa Catarina. XIX Congresso Brasileiro de Mecânica dos Solos e Engenharia Geotécnica, Salvador.

28. O.J. Pejon. (1992). Mapeamento Geotécnico Regional da Folha de Piracicaba-SP (Escala 1: 100.000): Estudo de Aspectos Metodológicos, de Caracterização e de Apresentação de Atributos. Tese, EESC/USP. São Carlos.

29. ASTM. (2017). Standard Practice for Classification of Soils for Engineering Purposes (Unified Soil Classification System). D2487-17. West Conshohocken. 